\title{
SKEPTICISM AND DAVIDSON'S OMNISCIENT INTERPRETER ARGUMENT
}

ANDREW WARD

St. Olaf College

Northfield, Minnesota

In a number of his papers Donald Davidson appeals to the intelligibility of an Omniscient Interpreter in order to undercut the traditional skeptical contention that human beings may have a coherent system of beliefs that are comprehensively false about the actual world (CT, p. 309). ${ }^{1}$ As Davidson says:

... it is plain why massive error about the world is simply unintelligible, for to suppose it intelligible is to suppose there could be an interpreter (the omniscient one) who correctly interpreted someone else as being massively mistaken, and this... [is] impossible (MTM, p. 201).

This argument against the skeptic lies at the center of Davidson's claim that using the coherence of beliefs (sentences held true) as a test of truth allows us to "be realists in all departments" (CT, p. 307). Specifically, Davidson contends that with the acceptance of coherence as a test of truth "[W]e can accept objective truth conditions

1 In what follows ' $C T$ ' will be used to refer to "A Coherence Theory of Truth and Knowledge", 'EC' to "Empirical Content", 'ME' to "Mental Events", 'MTM' to "The Method of Truth in Metaphysics", 'POPC' to "Philosophy of Psychology: Comments and Replay", 'RA' to "Rational Animals", 'RI' to "Radical Interpretation", 'TT' to "Thought and Talk", and 'VICS' to "On the Very Idea of a Conceptual Scheme". 
as the key to meaning, a realist view of truth, and we can insist that knowledge is of an objective world independent of our thought or language" (CT, p. 307). ${ }^{2}$ This having been said, it is important to keep in mind that Davidson's version of realism, what Michael Dummett calls "semantic realism", is not identical with what Hilary Putnam calls "metaphysical realism" (see Putnam, 1981: pp. $124 \mathrm{ff}$ ). According to metaphysical realism, there is no connection between epistemology and metaphysics which would negate the possibility that humans' beliefs about the actual world may all cohere with one another and yet be comprehensively false. In contrast, while a Davidsonian coherence test of truth will allow that any one of a person's beliefs may be false, it will not allow that most of that person's beliefs are false. ${ }^{3}$ As noted above though, this is just what the traditional skeptic is contending - viz., that it is intelligible (i.e. that it is epistemically possible to believe) that human beings have a coherent system of beliefs that "hang together and yet... [are] comprehensively false about the actual world" (CT, p. 309). Accordingly, if Davidson intends to use the coherence of beliefs to support his anti-skeptical

2 It is important to note that using coherence as a test of truth does not entail that truth is defined in terms of coherence (see CT, p. 308). More on this point will be brought out later.

${ }^{3}$ See CT, p. 309, EC, p. 322, and TT, p. 168. Davidson's use of 'most' cannot be a simple measure of the ratio of true beliefs to false beliefs since there could be an infinite number of both (see TT, p. 169). As Bruce Vermazen puts it:

Charity. . [Davidson says] must optimize agreement rather than maximize it, and optimizing. . . has to do with what sorts of beliefs agree. To use Quine's network-of-belief metaphor, it seems to be the beliefs near the center whose agreement contributes to optimizing (Vermazen, 1983: p. 71n).

It follows that the use of 'most' in Davidson's account is as a measure of optimization, "not numbers of beliefs" (Vermazen, 1983: p. 71n). Also see CT, p. 308, and LePore, pp. $327 \mathrm{ff}$. 
position that we can have knowledge "of an objective world independent of our thought or language", then he must provide an answer to the skeptic's claim. Although it is the goal of the Omniscient Interpreter argument to link the coherence of beliefs with knowledge of "an objective public world which is not of our own making" (CT, p. 310) in such a way as to answer the skeptic, Davidson nowhere provides a full account of the argument. Because of this, Davidson's use of the idea of an Omniscient Interpreter has given rise to a number of criticisms. For example, Niall Shanks and John King-Farlow write that "this being may be found ... to fall into ... philosophical embarrassment - to shed yet more analytical teeth if we take the idea of such as being ... very seriously indeed" (Shanks and King-Farlow, p. 118). While Jonathan Bennett writes that the thought of an Omniscient Interpreter "reminds us of the implausibility of the claim that any interpreter of X's thought and speech must share most of X's beliefs" (Bennett, p. 610). Contrary to these and other critical assessments of Davidson's Omniscient Interpreter argument, I will argue that Davidson's use of the idea of an Omniscient Interpreter is plausible, and does "rescue us from a standard form of skepticism" (CT, p. 319).

With the above goal in mind, let me offer the following informal reconstruction of Davidson's argument:

1. Suppose that the skeptic grants the intelligibility ${ }^{4}$ of a language user having all and only true beliefs -call him/her the (doxastically) Omniscient Interpreter $(\mathrm{OI}) .^{5}$ to believe.

1 Where, as noted above, intelligibility means epistemically possible

${ }^{5}$ See MTM, p. 201. One might object that no reasons have been given that would account for the skeptic's concession that an Omniscient 
2. According to Davidson, "[I]f we cannot find a way to interpret the utterances and other behavior of a creature... we have no reason to count that creature... as saying anything" (RI, p. 137). Put differently, "... interpretation is essentially translation... [and] if translation fails, there is no ground for speaking of two [conceptual schemes]" (POPC, p. 243).

3. From (1) and (2) it follows that the intelligibility of an OI requires that we are, in principle, able to interpret the language of that OI. ${ }^{6}$ As Davidson says, "a form of activity that cannot be interpreted as language in our language is not speech behavior" (VICS, pp. 185, 186). ${ }^{7}$

4. A necessary condition for interpretation is that the interpreter and the creature being interpreted share a coherent system of beliefs "since too great deviations from consistency... leave no common ground on which to judge either conformity or difference" (CT, p. 316). ${ }^{8}$ The general point here is that because beliefs are "identified and described only within a dense pattern of beliefs... [then] much community of belief is needed to provide a basis for communication or understanding" (MTM, p. 200).

5. Thus, if an OI is intelligible, then it must be because we share a coherent system of beliefs with that OI. If we did not share a coherent system of beliefs with

Interpreter is believable. Since an Omniscient Interpreter is a language user having all and only true beliefs, a skeptic who did not concede the believability of an Omniscient Interpreter would not concede the ability to believe that any belief was true. This form of skepticism cannot be answered by any argument.

6 The qualifier of 'in principle' is important. For a discussion of issues related to the qualifier see Glymour, pp. $171 \mathrm{ff}$.

7 Also see RI, p. 137.

8 Also see Vermazen, 1983: p. 70. 
an OI, then we could not grant the intelligibility of such a language user.

6. But in (1) it was supposed that the skeptic granted the intelligibility of an OI who, by definition, has all and only true beliefs.

7. Thus, it is not the case that we have a coherent system of beliefs that are comprehensively false about the actual world, and traditional skepticism. has been undercut. ${ }^{9}$

What now of the skeptical contention that it is intelligible that there is a language user whose "perceptual bad luck and intellectual frailty should coincide so as to make most of its beliefs about 'simple or obvious' matters false"? (Bennett, p. 610). From the argument above it follows that most of our own beliefs are true and so, by (4), if we could interpret this language user then most of his/her beliefs must be true. ${ }^{10}$ But this violates the assumption that most of his/her beliefs are false. Hence, by (4) we could not interpret his/her language and, as a result, have no reason to believe that he/she is a language user. The upshot is that if one accepts Davidson's argument, then the very idea of a language user having a coherent system of beliefs that are comprehensively false about the actual world, is unintelligible.

Having said this, there are still a number of objections that might be raised to the reconstruction of Davidson's argument offered above. For example, Jonathan Bennett claims that "a mostly false corpus of beliefs might be understood, on the basis of a complete agreement, by an in-

8 My formulation of Davidson's Omniscient Interpreter argument is not the orthodox formulation. Most commentators focus on whether or not it is intelligible to suppose that an Omniscient Interpreter could interpret a finite language user with all, or mostly false beliefs. For example, see Foley and Fumerton, pp. 83-89, Genova, pp. 1-6, and Rasmussen, pp. 315-319.

10 See my note 3 above. 
terpreter whose own beliefs were mostly false" (Bennett, p. 610; also see CT, p. 317). Here the idea is that even if one concedes to Davidson that beliefs are "identified and described only within a dense pattern of beliefs" (MTM, p. 200), this is not sufficient to justify the claim that most of the beliefs within the pattern must be true. As Colin McGinn notes, just as "holism with respect to meaning, such as Quine espouses, does not require that the totality of sentences in which a given sentence is embedded and from whose over-all semantic content its meaning is derived, be mainly true" (McGinn, 1977: p. 525), so too a holistic conception of belief content attribution does not require "that any of the beliefs... thus interrelated are true" (McGinn, 1977: p. 525).

In response to this line of objection Davidson says that "[F]alse beliefs tend to undermine the identification of the subject matter; to undermine, therefore, the validity of a description of the belief as being about the subject" (TT, p. 168). In other words, we can be said to have a belief about something only if we have an indefinitely large number of related true beliefs. Without a coherent pattern of largely true beliefs as background, there is nothing upon which any agreement or disagreement can focus, and so no basis for attributing content to the beliefs. ${ }^{11}$ Thus, Davidson will not allow the occurrence of the situation that Bennett describes.

Unfortunately, this response to the objection that Bennett raises will not work. To begin with, Davidson distinguishes the case of a sentence being held true and the sentence "being in fact true" (TT, pp. 169-170). ${ }^{12}$ A sentence may be held true whether or not the sentence really is true. Because of this, Davidson says that the "attitude

See TT, p. 168, and MTM, p. 200.

Also see BBM, p. 153. 
of holding true" corresponds "directly to belief" (TT, p. 170). When a sentence held true really is true, we may say that the person holding the sentence to be true has a true belief. In contrast, when a sentence held true really is false, we may say that the person holding the sentence to be true has a false belief. What this points out is that the characterization of a belief as being either true or false presupposes the identification of that belief. To suppose otherwise is a tantamount to saying that what warrants attributing a particular content to a belief is that there is some correspondence relation between the belief and the world (or some mediating representation of the world such as sense-data). However, to say that what warrants attributing a particular content to a belief is that the belief stands in a correspondence relation to the world faces at least two problems. First, it conflicts with Davidson's own claim that "we make sense of particular beliefs only as they cohere with other beliefs..." (ME, p. 221) ${ }^{13}$ by conflating a coherence theory of truth with a coherence theory of warranted attributions of belief content. For Davidson it is important to keep separate the question of whether or not the condition that makes a sentence true obtains, from the question of what warrants attributing a particular content to a sentence. Since beliefs are, for Davidson, sentences held true, then while correspondence accounts for the truth of a belief, it is coherence that accounts for the attributed content. The important point is that Davidson's commitment to a correspondence theory of truth does not commit him to a correspondence theory of warranted attributions of content, and his commitment to a coherence theory of warranted attributions of content does not commit him to a coherence theory of truth ( $\mathrm{CT}, \mathrm{p} .308)$. The second 
problem with identifying beliefs exclusively in terms of a particular correspondence relation in which they stand to the world is that it is difficult to see how there could be false beliefs. Beliefs that seemed to be false would be beliefs to which the wrong content had been mistakenly attributed. In contrast, if Davidson says that what warrants the identification of a belief is its "location in a pattern of beliefs" and that "it is this pattern that determines the subject matter of the belief, what the belief is about" (TT, p. 168 -my emphasis), then it will not do for Davidson to say that most beliefs are correct because "a belief is identified by its location in a pattern of beliefs..." (TT, p. 168). Although it is the location of a belief in a pattern of beliefs "that determines the subject matter of the belief, what the belief is about" (TT, p. 168), it does not, as McGinn notes, follow that any of the beliefs thus interrelated are true (McGinn, 1977: p. 525). Short of the Omniscient Interpreter argument, there is nothing to preclude the situation Bennett describes wherein a mostly false corpus of beliefs provide the doxastic background necessary for attributing content to individual beliefs. Thus, it would seem that the most that Davidson has shown is that an interpreter having a coherent system of beliefs, most of whose members are false, could not interpret someone having a coherent system of beliefs, most of whose members are true (and vice versa).

In light of these problems, it seems to me that a better response would be for Davidson to say that the situation described by Bennett is fundamentally incoherent precisely because the Omniscient Interpreter argument shows that we do have a coherent system of beliefs, most of whose members are true. As noted earlier, the point of the Omniscient Interpreter argument is to suggest that the notion of a person whose "perceptual bad luck 
and intellectual frailty should coincide so as to make most of... [their] beliefs about 'simple or obvious' matters false" is, really unintelligible. Accordingly, what the argument suggest is that the situation Bennett describes either begs the question in favor of the skeptic or else simply makes no sense. On this reading, the trick is not to solve Bennett's objection, it is to dissolve it.

However, Bennett does not leave matters here. As noted earlier, he continues his critique of Davidson with:

The thought of an omniscient interpreter reminds us of the implausibility of the claim that any interpreter of x's thought and speech must share most of $x$ 's beliefs (Bennett, p. 611).

Bennett's point is that Davidson has drawn the connection between an interpreter's beliefs and an interpretee's beliefs too tightly. In contrast, Bennett wants to drive a wedge between the two sets of beliefs such that the ability of an interpreter to interpret the linguistic behavior of a person does not depend upon the two sharing a coherent system of beliefs. Relative to the reconstructed argument offered above, Bennett can be read as claiming that (4) is false. The idea is that the first stages of the Davidsonian argument can be turned upside down as a reductio against (4). In particular:

(1') An OI is intelligible.

$\left(2^{\prime}\right)$ "[I]f we cannot find a way to interpret the utterances and other behavior of a creature... we have no reason to count that creature... as saying anything"(RI, p. 137). ${ }^{14}$

$\left(3^{\prime}\right)$ Thus, we are in principle able to interpret the language of an OI.

$\left(3^{\prime \prime}\right)$ The OI, by definition, has all and only true beliefs,

14 Also see VICS, pp. 185-196. 
whereas it is intelligible to suppose that we have mostly false beliefs.

$\left(4^{\prime}\right)$ Thus, interpretation does not require that the interpreter and the interpretee share a coherent system of beliefs.

If correct, then Bennett will have undermined a necessary assumption of Davidson's argument against skepticism.

So, is Bennett right or wrong? Well to begin with, notice that the crucial step in the above rendition of Bennett's argument is $\left(3^{\prime \prime}\right)$, which assumes the negation of the conclusion of the Omniscient Interpreter argument -namely that it is intelligible to suppose that we have a coherent system of beliefs that are comprehensively false about the actual world. Accordingly, the real question is why we ought to grant Bennett the point that it is intelligible to suppose that we have a coherent system of beliefs that are comprehensively false about the actual world. Here, it seems to me, the most obvious examples that would tend to support such a supposition are the examples of paradigm shifts made famous by Thomas Kuhn (Kuhn, p. 134). What such examples are sometimes said to show is that scientists operating in different scientific paradigms are really working "in different worlds" (Trigg, chapter 4). If cogent, these examples suggest that our own conceptual picture of the world is best thought of as a historical phase we are passing through which will, in the future, be replaced by some different set of scientific paradigms. In summary then, the history of scientific revolutions seem to suggest that our own beliefs, like those of our predecessors, may well be both coherent and, for the most part, false. ${ }^{15}$

Davidson, though, will have none of this. Reading

15 See Rorty, 1982: p. 8, and Vermazen, 1983: p. 72. For a different, but related example, see Shanks and King-Farlow, pp. $116 \mathrm{ff}$. 
Kuhn's notion of incommensurable as synonimous with untranslatable, Davidson says that the appeal to changing scientific paradigms supports the claim that most of our beliefs may be false only if it entails a separation of the "organizing system and something waiting to be organized..." (VICS, p. 190). But this bifurcation, what is sometimes called the third dogma of empiricism, "cannot be made intelligible and defensible" (VICS, p. 189) because "the concepts of objective truth, and of error, necessarily emerge in the context of interpretation" (TT, p. 169). That is to say, it is only against a public norm that someone can have the concepts of objective and subjective truth, and such a norm can only be provided by language. ${ }^{16}$ Thus, for Davidson it makes no sense to adopt a dualism of scheme and content; the two are inseparably bound together as elements of linguistic practice. This means that past paradigms can be recognized as paradigms only if there is some broader shared linguistic framework into which both they and their replacement fit (VICS, p. 184). In turn, what follows is that the intelligibility of Kuhnian paradigm shifts presupposes a shared conceptual picture of the world rather than telling against it. As Barry Stroud says:

No revision open to us can take us beyond the language we now use and understand - any 'alternative' is either something we already understand and can make sense of, or it is no alternative at all (Stroud, p. 92).

Of course by itself this falls short of showing that the coherent system of shared beliefs, the conceptual picture, is made up of beliefs which, for the most part, are true. On the other hand, what it does suggest is that there are good reasons to accept (4) in the reconstructed version of Davidson's Omniscient Interpreter argument. In this

${ }^{16}$ See TT, pp. 167, 170, and RA, p. 327. 
case though, the argument seems to go through and there is no reason for accepting the claim that we may have a coherent system of beliefs that are comprehensively false about the actual world.

A final objection that could be raised against the Omniscient Interpreter argument is that a person, when presented with an actual OI, might in fact be unable to interpret the OI's language behavior and so conclude that the OI was not a language user at all. It is tempting to conclude that this shows that a distinction should be drawn between an OI's being intelligible and its merely being construed as intelligible. What makes an OI intelligible to a person, so the objection runs, is that its language can in fact be interpreted by the person. Thus, if when presented with any actual OI a person is unable to interpret its language use, then the notion of a language user having all and only true beliefs is not really intelligible for that person. If correct, the most that follows from my reconstruction of Davidson's argument is that if someone can in fact interpret the language of an OI, then that person has a coherent system of beliefs which, for the most part, are true.

Unfortunately, this weakened conclusion is not strong enough to undermine the form of skepticism that concerns Davidson. What remains open on this account is the possibility that there are people for whom an OI is construed as intelligible, but is not really intelligible because they have a coherent system of beliefs that are comprehensively false about the actual world. It follows that short of showing that every possible finite interpreter is in fact able to interpret an OI, something whose likelihood seems quite small, the reconstructed version of Davidson's Omniscient Interpreter argument fails to un- 
dermine skepticism. ${ }^{17}$ In answer to this objection, begin by recalling that according to (3), the intelligibility of an OI requires only that the skeptic be able in principle to interpret the language of the OI. But this is just an instance of the more general point that intelligibility requires only the possibility of interpretation (VICS, pp. 185, 186). Now it's true that one might object here that the possibility of interpretation can only be shown by offering an actual interpretation ${ }^{18}$ and that, according to the above objection, it is this that is missing. As has already been noted though, for Davidson the concepts of (objective) truth and falsity emerge only within the context of interpretation. ${ }^{19}$ Thus, any discussion of an interpreter having all and only true beliefs (i.e., being omniscient) is dependent upon the specification of the interpreter's language. Relative to the above objection, the language that is of interest is the skeptic's. In particular, what is at issue is wether there is an OI who is a user of the skeptic's language. Here it is important to note that because the skeptic is, by assumption, a language user, it follows that there is a public norm provided by that language against which the skeptic's beliefs may be said to be either (objectively) true or false. ${ }^{20}$ Thus, the very fact that the skeptic is a language user presupposes the intelligibility of the notions of (objective) truth and falsity. Moreover, since the OI just is that language user who has all and only true beliefs, then the very fact that skeptic uses the language he/she does entails the intelligibility of an OI who uses that same language. Granted that an individual (finite) language user might not in fact be able to interpret an OI using the same language,

${ }^{17}$ I owe this point to A. C. Genova.

18 I owe this point to Michael Root.

19 See TT, p. 169, and VICS, p. 189.

20 See TT, p. 169 , and RA, p. 327. 
but this only reflects the limitations of finite language users vis $\dot{a}$ vis the potentially infinite character of their language. The upshot is that, contrary to the above suggestion, the possibility of interpretation of an OI by the skeptic is a consequence of the skeptic's being a language user.

Finally then, conjoined with the principle (at (4)) that a necessary (though not sufficient) condition for interpretability is that the interpreter and interpretee share a coherent system of beliefs with one another, it follows that if both an OI and a language user possessing a coherent system of beliefs that are comprehensively false about the actual world are intelligible to a person, then the person must share a coherent system of belief with both. But this requires the person to have a coherent system of beliefs which, for the most part, are both true and false. Patently such a situation embodies a contradiction. What is important to keep in mind is that whether or not a person is able in fact to recognize an actual OI makes no difference. The possibility of interpretation does not require that an actual interpretation occur. Instead, what is important is that the person grants the intelligibility of an OI and that the intelligibility of an OI requires only that the person be able, in principle, to interpret an OI's language. Once these points are granted, (4) precludes the intelligibility of supposing the person to have a coherent system of beliefs that are comprehensively false about the actual world.

In conclusion, if the skeptic grants both the genuine intelligibility of a language user having all and only true beliefs (an Omniscient Interpreter) and Davidson's method of (radical) interpretation, then the skeptical contention that human being may have a coherent system of beliefs that are comprehensively false about the actual world is 
undermined and we can, in Davidson's words, "be realists in all departments".21

\section{BIBLIOGRAPHY}

Bennett, Jonathan, "Critical Notice: Inquiries into Truth and Interpretation", Mind, v. 94, n. 376 (October, 1985), pp. 601626.

Berriman, W. A., "Alternative Conceptual Schemes", Metaphilosophy, v. 9, nos. 3, 4 (July/October, 1978), pp. 226-232.

Collin, Finn, "Meta-Constraints Upon Interpretation", American Philosophical Quarterly, v. 24, n. 2 (April, 1987), pp.137-148.

Davidson, Donald, "Empirical Content", in Truth and Interpretation: Perspectives on the Philosophy of Donald Davidson, pp. 320-332.

- Essays on Actions and Events (Oxford: Clarendon Press, 1982).

- Inquiries Into Truth and Interpretation (Oxford, Clarendon Press, 1984).

—_, "Rational Animals", Dialectica, v. 36, n. 4 (1982), pp. 317327.

Dostal, Robert J., "The World Never Lost: The Hermeneutics of Trust", Philosophy and Phenomenological Research, v. 47, n. 3 (March, 1987), pp. 413-434.

Eldridge, Richard, "Metaphysics and the Interpretation of Persons: Davidson on Thinking and Conceptual Schemes", Synthese, v. 66 , n. 3 (March, 1986), pp. 477-503.

- -The Normal and the Normative: Wittgenstein's Legacy, Kripke, and Cavell", Philosophy and Phenomenological Research, v. 46, n. 4 (June, 1986), pp. 555-575.

Foley, Richard, and Richard Fumerton, "Davidson Theism?", Philosophical Studies, v. 48, n. 1 (July, 1985), pp. 83-89.

Frede, Dorothea, "Beyond Realism and Anti-Realism: Rorty on Heidegger and Davidson", The Review of Methaphysics, v. 40, n. 4 (June, 1987), pp. 733-757.

Genova, A. C., "Davidson's Omniscient Interpreter Argument, or the Very Idea of Massive Error", unpublished.

Glymour, Clark, "Conceptual Scheming ar Confessions of a Metaphysical Realist", Synthese, v. 51, n. 2 (May, 1982), pp. 169-180.

21 I would like to thank John Bricke, A. C. Genova and Michael Root for helpful comments on earlier drafts of this paper. 
Holt, David, and Melvin Ulm, "Conceptual Frameworks and Realism", Metaphilosophy, v. 13, n. 1 (January, 1982), pp. 31-45.

Janssens, C. J. A. M., and J. van Brakel, "Davidson's Omniscient Interpreter", unpublished.

Klein, Peter D., "Radical Interpretation and Global Skepticism", in Truth and Interpretation: Perspectives on the Philosophy of Donald Davidson, pp. 369-386.

Lear, Jonathan, "Leaving the World Alone", The Journal of Philosophy, v. 79, n. 7 (July, 1982), pp. 382-403.

LePore, Ernest, "Interpretation, Belief, and Behavior", Philosophia, v. 12, nos. 3, 4 (March, 1983), pp. 323-336.

McGinn, Colin, "Charity, Interpretation, and Belief", The Journal of Philosophy, v. 74, n. 9 (September, 1977), pp. 521-535.

- "Radical Interpretation and Epistemology", in Truth and Interpretation: Perspectives on the Philosophy of Donald Davidson, pp. 356-368.

Maker, William, "Davidson's Trascendental Arguments", unpublished.

Malpas, J. E., "Shanks, King-Farlow, and the Refutation of Davidson", Idealistic Studies, v. 18, n. 1 (January, 1988), pp. 20-31.

Mulhall, Stephen, "Davidson on Interpretation and Understanding", The Philosophical Quarterly, v. 37, n. 148 (July, 1987), pp. 319-322.

Rasmussen, Stig Alstruip, "The Intelligibility of Abortive Omniscience", The Philosophical Quarterly, v. 37, n. 148 (July, 1987), pp. 315-319.

Rescher, Nicholas, "Conceptual Schemes", in Midwest Studies in Philosophy, Volume V: Studies in Epistemology, edited by Peter French, Theodore Uehling Jr. and Howard Wettstein (Minneapolis: University of Minnesota Press, 1980), pp. 323-345.

Rorty, Richard, "The World Well Lost", The Journal of Philosophy, v. 69, n. 18 (October 5, 1972), pp. 649-665.

Shanks, Niall, and John King-Farlow, "Davidson and the Refutation of Idealism", Idealistic Studies, v. 16, n. 2 (May, 1986), pp. 113-123.

Sosa, Ernest, "'Circular' Coherence and 'Absurd' Foundation", in Truth and Interpretation: Perspectives on the Philosophy of Donald Davidson, pp. 387-397.

Stoutland, Frederick, "Realism and Anti-Realism in Davidson's Philosophy of Language (I)", Crítica, v. XIV, n. 41 (August, 1982), pp. 13-53.

- "Realism and Anti-Realism in Davidson's Philosophy of Language (II)", Crítica, v. XIV, n. 42 (December, 1982), pp. 1948.

Truth and Interpretation: Perspectives on the Philosophy of Don- 
ald Davidson, edited by Ernest LePore (Oxford: Basil Blackwell, 1986).

Vermazen, Bruce, "General Beliefs and the Principle of Charity", Philosophical Studies, v. 42, n. 1 (July, 1982), pp. 111-118.

- "The Intelligibility of Massive Error", The Philosophical Quarterly, v. 33, n. 130 (January, 1983), pp..69-74.

Recibido: 18 enero 1989. 